\title{
Firm racial segregation and affirmative action in the highway construction industry
}

\author{
Justin Marion
}

Accepted: 9 January 2009/Published online: 6 May 2009

(C) The Author(s) 2009. This article is published with open access at Springerlink.com

\begin{abstract}
In this paper I document that highway construction firms in California, particularly those owned by blacks and Asians, exhibit considerable racial segregation in that they are disproportionately located in zip codes with the greatest concentration of own-race residents. I find that segregated firms serve a larger market than minority-owned firms that are not segregated and that this effect is concentrated in black-owned firms. I next exploit the segregation of firms to examine the effect of affirmative action on the success of minority-owned firms. Following the significant curtailment of affirmative action in California due to a direct statewide ballot initiative, the number of highway construction establishments located in zip codes with the highest concentrations of black and Asian residents fell relative to the rest of the state, even conditional on the number of nonconstruction establishments. This suggests that affirmative action policies may play a role in the net survival rates of minority-owned firms.
\end{abstract}

Keywords Affirmative action - Highway construction - Racial segregation · Public procurement

\section{JEL Classifications L26}

J. Marion $(\bowtie)$

Economics Department, University of California, 401 Engineering 2 Building, Santa Cruz, CA 95064, USA

e-mail: marion@ucsc.edu

\section{Introduction}

Segregation along racial lines is a common feature of the organization of cities, and this pattern of racial segregation tends to be highly correlated with the location of economic disadvantage within a city. As a consequence, racial segregation has been an important area of study for those trying to understand racial gaps in measures of economic well-being. Much of the focus has centered on the location of employment within a city in relation to the location of racial and ethnic enclaves. The so-called spatial mismatch hypothesis, first advanced by Kain (1968), suggests that minority unemployment may in part be due to geographic patterns of employment and residence, where minorities are segregated into central cities while employment opportunities are concentrated in suburbs. ${ }^{1}$ Encouraging business ownership among minorities, potentially through affirmative action programs, may help alleviate this problem if minority-owned firms locate near minority population centers. Establishing the impact of affirmative action on minority firms is an important part of the current policy debate due to the recent curtailment of affirmative action programs through the courts and voter

\footnotetext{
$\overline{1}$ Holzer (1991) provides a literature review on the spatial mismatch hypothesis. Empirical evidence regarding the spatial mismatch hypothesis include Raphael (1998), Stoll (1999a, b), Cutler and Glaeser (1997), Stoll et al. (2000), and Brueckner and Zenou (2003).
} 
initiatives and due to the potential cost of these programs (Marion forthcoming $b$ ).

In this paper, I investigate the location of minorityowned firms in the highway construction industry and how affirmative action may affect the success of firms located in neighborhoods with the highest concentrations of minority residents. Highway construction and repair is an important public procurement market that makes intensive use of affirmative action programs. In 1998, states awarded US\$14.6 billion of construction and repair contracts using federal funds, of which US $\$ 1.9$ billion was awarded to firms owned by minorities and women. In addition, most states and many counties and cities also use affirmative action to direct locally funded projects to firms owned by minorities and women.

I first utilize the directory of disadvantaged business enterprises (DBEs) that are pre-qualified to perform work on California Department of Transportation (Caltrans) road construction and repair projects. I find that the location of firms in this industry closely corresponds to patterns of residential location by race-black-owned firms are disproportionately likely to locate in zip codes with higher concentrations of black residents, Hispanic-owned firms are disproportionately likely to locate in Hispanic areas, and so forth. ${ }^{2}$ I will refer to this pattern as firm segregation. ${ }^{3}$

The extent to which this segregation affects the success of firms owned by minorities is an important question. ${ }^{4}$ By locating in minority areas, firms may limit their access to capital and to prime contractors. On the other hand, own-race networks may be positive factors in firm success. Firms may face

\footnotetext{
$\overline{2}$ The zip code may not be the ideal level of geography to evaluate racial segregation since its boundaries may match poorly with those of racial neighborhoods. However, I prefer this level of geography here since the findings related to firm segregation will aid in the interpretation of the results where I examine establishment counts at the zip code level.

${ }^{3}$ While I will use the term segregation to describe the location of firms in own-race neighborhoods, the evidence I will present suggests that firms locate in areas that are only disproportionately comprised of own-race residents. For instance, blackowned firms are far more likely to locate in areas where at least $20 \%$ of the population is black than are other firms. However, more than half of black-owned firms locate in zip codes where less than $20 \%$ of the population is black.

${ }^{4}$ For a detailed discussion of factors affecting the success of black-owned businesses, see Fairlie and Robb (2007).
}

discrimination in terms of obtaining business, leasing land, and forming networks in predominantly white neighborhoods. Furthermore, common cultural ties can make enforcing informal contracts easier. ${ }^{5}$

To investigate this question, I examine the breadth of a firm's capabilities as measured by the number of districts in which the firm is prequalified to perform work. I find that black- and Hispanic-owned firms are able to serve smaller areas than Asian- and whiteowned firms. Interestingly, segregated minorityowned firms, those located in zip codes with high own-race population concentrations, are able to serve larger markets than non-segregated firms. Furthermore, the effect of segregation on firms' market size is uneven among races. Segregated black-owned firms experience a significantly positive segregation effect, while segregation has a much smaller and statistically insignificant effect on the capabilities of firms owned by Hispanics and Asians. Since firm location is an endogenous variable, this may explain why black firms experience a greater degree of segregation.

Having established that minority-owned firms do tend to locate in areas with a greater composition of minority residents, this paper lastly examines the effect of affirmative action on firms in minority areas. $^{6}$ I use the implementation of California's Proposition 209, which eliminated the consideration of race and gender in the awarding of state contracts, to provide evidence on the effect of affirmative action on minority businesses and economic activity in minority neighborhoods. I focus in particular on highway construction establishments, as firms in this industry derive most of their revenue from public projects and are, therefore, the most subject to policies in public procurement. Using data from the

\footnotetext{
5 For instance, Gil and Hartmann (2007) examine dry cleaners located in Los Angeles' Koreatown, finding that drycleaners with Korean-speaking owners are less likely to be vertically integrated. This suggests that the costs of using the market are lower for firms with access to the social network. Other papers that consider the importance of social networks for business formation and success include those of Davidsson and Honig (2003), Kalnins and Chung (2005), Rauch (2001), and Shane and Cable (2002).

${ }^{6}$ In a related paper, Bollinger and Ihlanfeldt (2003) examine the effect of various government interventions on the pattern of employment within a city.
} 
Zip Code Business Patterns, I find that the initiative's implementation coincided with a decline of 2.6 and $2.1 \%$ in the likelihood of zip codes in the fifth quintile of the black and Asian population distribution, respectively, having a highway construction establishment. I find that zip codes in the fifth quintile of the Hispanic distribution, in contrast, saw an increase in the likelihood of having an establishment. The racial location of Hispanic-owned firms is more evenly spread across the Hispanic population distribution, which may help explain this finding.

Highway procurement is a useful setting for examining affirmative action for several reasons. First, the use of affirmative action is widespread in this setting. Since the late 1970s and early 1980s, most states have employed affirmative action to award contracts to minority-owned firms. Second, affirmative action programs in highway procurement are in general comparable across states. Most states use percentage goals for the participation of minorityowned subcontractors by prime contractors. This allows for comparison across states and furthermore allows one to more readily generalize results obtained from a particular state to other states. Finally, the highway construction industry is mostly comprised of firms selling to the government. According to the 2002 Census of Industries, $72.6 \%$ of the construction work performed by firms in the highway, street, and bridge construction industry was for governmentowned projects. As a result, changes in public procurement policy will have a strong effect on firms in the highway construction industry. This fact eases the burden placed on the data, as drawing inference regarding the effect of affirmative action on a given firm in the highway construction industry will provide more power than making the same inference regarding a firm in the broader construction industry.

While affirmative action has been found to increase the utilization of minority-owned firms in procurement (for example, Marion forthcoming a), its effects on business success and firm formation and survival have proven difficult to assess. Bates and Williams (1996) examine data from the Characteristics of Business Owners, utilizing a question in this survey that asks responding firms the revenues they derive from selling to the government. These researchers find that minority business owners who rely heavily on government contracts were more likely to fail between 1987 and 1991. Blanchflower and Wainwright (2005) utilize data from the Current Population Survey to examine whether self-employment rates among minorities and women were lower after federal affirmative action programs were weakened by the case of City of Richmond v. J.A. Croson Co. In this case, the Supreme Court ruled that raceconscious programs must meet strict scrutiny requirements establishing a compelling need for the program and that the program is narrowly tailored. Blanchflower and Wainwright (2005) find that self-employment rates among minorities and women were not significantly different post-Croson, despite the fact that many local affirmative action programs ended during this time. Chatterji et al. (2009) examine cities' adoption of affirmative action programs in procurement, finding that black self-employment rates rose dramatically in adopting cities. In contrast, Fairlie and Marion (2008) find that eliminating affirmative action in California and Washington was in fact associated with an increase in minority selfemployment rates in those states, possibly due to those same affirmative action programs also applying to labor markets, so their elimination may have lowered the opportunity cost to business formation.

This paper proceeds as follows. Section 2 provides background information on highway procurement in California and Caltrans' affirmative action program. Section 3 describes the data that will be used; Sect. 4 presents the results, and Sect. 5 concludes.

\section{Background}

Until March of 1998, the California Department of Transportation (Caltrans) set a statewide goal for the participation of DBEs on state highway construction, which it met by applying a DBE subcontractor participation goal on a project-by-project basis. To qualify as a DBE, a firm must meet two requirements: an ownership requirement that at least $51 \%$ of a business must be owned by the group for which the goal applies, and an operations requirement that the minority or female owners be involved in the day-today operation of the business.

Firms bidding for construction contracts must supply a list of the subcontractors to be used in the completion of the project. A qualifying bid either meets the participation goal stipulated in the contract or documents a good faith effort to locate DBEs in 
the event that the participation goal is not met. Bids are often rejected for failing one of these two tests. From May 1996 until the end of 2002, 36 low bids were rejected on this basis.

In June 1996, voters in California passed a statewide referendum, Proposition 209, which was intended to eliminate the consideration of race and gender in state contracting, education, and employment. This ballot initiative affected projects using only state funds. The application of Proposition 209 to many state programs was delayed because the California constitution states that local agencies will continue to enforce state statutes until they are repealed by the legislature or ruled unconstitutional by the courts. There also remained ambiguities regarding which programs Proposition 209 actually covered. A federal appeals court in 1997 upheld Proposition 209, but participation goals continued to be used by Caltrans throughout 1997 and into 1998 . Two relevant legal decisions were delivered in early 1998, Hi-Voltage Wire Works v. City of San Jose and Monterey Mechanical v. Wilson, both coming down against the use of participation goals in contracting. Following these court rulings, in March of 1998 California Governor Pete Wilson issued an executive order stating that all state programs utilizing genderand race-based participation goals in the awarding of state contracts were to be immediately suspended.

The executive order affected only contracts funded entirely by the state, since eliminating affirmative action would potentially place funding from federal sources in jeopardy. Because approximately half of the road construction contracts awarded by the state used federal funds (Marion forthcoming b), Proposition 209 did not fully eliminate affirmative action in California; however, it significantly curtailed its use after 1998. At other levels of government, the last court decisions to rule against race-conscious affirmative action were decided in 2004.

\section{Data}

\subsection{Caltrans disadvantaged business enterprise directory}

Information regarding firms in this market is obtained from the DBE directory maintained by Caltrans. Based on capabilities, firms can gain pre-qualification to perform work on certain types of projects and certain locations. This directory contains information on all firms qualified to be counted as DBEs fulfilling the DBE subcontracting requirement in a contract. It also contains information on the firm's location, the work it is willing to perform, and the race of the owner. I exclude firms located outside California from analysis.

\subsection{Zip code business patterns}

The zip code business patterns data provide the number of establishments at the five digit zip code level. Establishments simply represent the unique geographic locations of firms, and several establishments can be owned by the same firm. These data provide the number of establishments at a detailed level of industry, which will in turn be used to identify the number of establishments specifically in the highway construction industry in a particular zip code. The data used in this paper are yearly information from 1994 to 2002, spanning the implementation of Proposition 209. A significant reclassification of industries occurred in 1997, when the Census transitioned from using Standard Industry Classification (SIC) codes to using North American Industry Classification System (NAICS) codes. The primary industry I focus on is Highway and Street Construction Contractors, Excluding Elevated Highways, SIC 1611/NAICS 234110, an industry providing a virtually perfect match between the two industry taxonomies. I also examine the construction industry more generally, which includes SIC 15/16/17 and NAICS 23. The correspondence between the two classifications is less precise here, with the discrepancies between the two due largely to NAICS including establishments specializing in management services within the construction industry. However, according to the bridge between the SIC and NAICS provided by the Census, $98 \%$ of establishments in NAICS 23 are in the SIC construction category, and NAICS 23 includes all establishments from the SIC construction category.

\section{Results}

\subsection{Firm segregation}

I begin by documenting the degree to which highway construction firms are geographically segregated 
along racial lines. Table 1 provides the distribution of firms over the racial concentration of zip codes. For example, in the top panel, I display the number of black-, Hispanic-, Asian-, and white-owned firms by the fraction of the zip code population that is black. The firms in the Caltrans DBE directory are relatively balanced across racial groups. Of the 1641 firms in the directory, 311 are black-owned, 480 are owned by Hispanics, 395 are owned by Asians, and 455 are owned by white females. Despite this balance, black firms are disproportionately located in zip codes with the highest proportion of black residents. Of the 23 firms located in zip codes where at least $60 \%$ of the population is black, 21 are black-owned. Furthermore, while only $10 \%$ of firms not owned by blacks are located in zip codes with at least a $20 \%$ black population, $48 \%$ of black-owned firms are located in these zip codes.

While black-owned firms seem to be the most highly segregated, a similar though less pronounced pattern emerges for Asian-owned firms. Asian-owned firms account for $24 \%$ of the firms in the directory, yet account for $55 \%$ of the 67 firms located in zip codes with a population that is at least $40 \%$ Asian. Hispanic-owned firms are less segregated by race, though some segregation is still noticeable. These firms account for $29 \%$ of the 1641 firms in the directory, yet account for $54 \%$ of firms in zip codes with a population at least $60 \%$ Hispanic.

Each of the cells in Fig. 1 has a different number of zip codes, making a comparison across population concentrations of different races difficult. For instance, far more zip codes have a black population share of less than $20 \%$ than have a Hispanic population share of less than $20 \%$. To directly account for this, I next divide zip codes into quintiles of their black population share, Hispanic population share, and Asian population share. I then plot the distribution of black-, Hispanic-, and Asian-owned firms across these quintiles. The advantage of this comparison is that the fifth quintile of zip codes based on black population share has the same number of zip codes as the fifth quintile of zip codes based on Hispanic population share.

The results of this exercise are plotted in Fig. 1. In Panel A, I consider how black-, Hispanic, and Asianowned firms are distributed across zip codes according to the percentage of the zip code population that is black. White, Hispanic, and Asian firms are distributed similarly across the black population, with more of these firms located in the third, fourth, and fifth quintiles of the black population. Thirtythree percent of white firms locate in zip codes in the highest quintile of black population zip codes, compared with $34 \%$ of Hispanic firms and $40 \%$ of Asian firms. However, black-owned firms overwhelmingly locate in black zip codes, as $72 \%$ of black-owned firms locate in zip codes in the fifth quintile of the black population distribution.

Panel B displays results from a similar exercise, where the distribution of firms is shown across the quintiles of zip codes' Hispanic population percentage. The results are far less striking than for the segregation of black-owned firms. Considering the highest quintile zip codes of Hispanic population, $32 \%$ of Hispanic firms locate there compared with $17 \%$ of Asian-owned firms and $18 \%$ of white-owned firms.

As with Black- and Hispanic-owned firms, Asianowned firms exhibit a considerable degree of segregation. Panel $\mathrm{C}$ plots the distribution of firms across quintiles of the Asian population. Sixty percent of Asian-owned firms are located in the highest quintile of the Asian population. This compares with $32 \%$ of Hispanic firms and $43 \%$ of black firms.

\subsection{Segregation and firm capabilities}

I next examine how the segregation documented in Sect. 4.1 correlates with firm capabilities. Segregation may limit the business networks of minority firms, which may affect access to capital and business markets. On the other hand, locating near suppliers or contractors that share common cultural links may enhance firm performance.

I consider the number of Caltrans districts in which firms are qualified to work. Figure 2 provides a map of these districts. There are 12 districts in the state, and each district is of considerable size, with the exception of district 12 , which is comprised entirely of Orange County. Conditional on the type of work the firm performs, market scope is a strong indication of the firm's breadth of capabilities. First, districts are large enough that a firm serving a separate district implies a firm with a sizable market, not merely a firm that must look outside of its immediate zip code to find work. Second, distance is an important element of the highway construction 
Table 1 Caltrans DBE firm location by racial composition of zip code

\begin{tabular}{|c|c|c|c|c|c|c|}
\hline & $<20 \%$ & $20-40 \%$ & $40-60 \%$ & $60-80 \%$ & $>80 \%$ & Number of firms \\
\hline \multicolumn{7}{|c|}{ Percentage of zip code Black } \\
\hline \multirow[t]{2}{*}{ Black firms } & 161 & 43 & 86 & 20 & 1 & 311 \\
\hline & $51.8 \%$ & $13.8 \%$ & $27.7 \%$ & $6.4 \%$ & $0.3 \%$ & \\
\hline \multirow[t]{2}{*}{ Hispanic firms } & 452 & 14 & 14 & 0 & 0 & 480 \\
\hline & $94.2 \%$ & $2.9 \%$ & $2.9 \%$ & $0.0 \%$ & $0.0 \%$ & \\
\hline \multirow[t]{2}{*}{ Asian firms } & 330 & 19 & 45 & 1 & 0 & 395 \\
\hline & $83.5 \%$ & $4.8 \%$ & $11.4 \%$ & $0.3 \%$ & $0.0 \%$ & \\
\hline \multirow[t]{2}{*}{ White female firms } & 413 & 25 & 16 & 1 & 0 & 455 \\
\hline & $90.8 \%$ & $5.5 \%$ & $3.5 \%$ & $0.2 \%$ & $0.0 \%$ & \\
\hline \multirow[t]{2}{*}{ Number of firms } & 1356 & 101 & 161 & 22 & 1 & 1641 \\
\hline & $82.6 \%$ & $6.2 \%$ & $9.8 \%$ & $1.3 \%$ & $0.1 \%$ & \\
\hline \multirow[t]{2}{*}{ Zip codes } & 1593 & 48 & 17 & 5 & 1 & \\
\hline & $95.7 \%$ & $2.9 \%$ & $1.0 \%$ & $0.3 \%$ & $0.1 \%$ & \\
\hline \multicolumn{7}{|c|}{ Percentage of zip code Black } \\
\hline \multirow[t]{2}{*}{ Black firms } & 138 & 96 & 62 & 12 & 3 & 311 \\
\hline & $44.4 \%$ & $30.9 \%$ & $19.9 \%$ & $3.9 \%$ & $1.0 \%$ & \\
\hline \multirow[t]{2}{*}{ Hispanic firms } & 192 & 126 & 77 & 60 & 25 & 480 \\
\hline & $40.0 \%$ & $26.3 \%$ & $16.0 \%$ & $12.5 \%$ & $5.2 \%$ & \\
\hline \multirow[t]{2}{*}{ Asian firms } & 226 & 92 & 42 & 29 & 6 & 395 \\
\hline & $57.2 \%$ & $23.3 \%$ & $10.6 \%$ & $7.3 \%$ & $1.5 \%$ & \\
\hline \multirow[t]{2}{*}{ White female firms } & 282 & 106 & 44 & 17 & 6 & 455 \\
\hline & $62.0 \%$ & $23.3 \%$ & $9.7 \%$ & $3.7 \%$ & $1.3 \%$ & \\
\hline \multirow[t]{2}{*}{ Number of firms } & 838 & 420 & 225 & 118 & 40 & 1641 \\
\hline & $51.1 \%$ & $25.6 \%$ & $13.7 \%$ & $7.2 \%$ & $2.4 \%$ & \\
\hline \multirow[t]{2}{*}{ Zip codes } & 958 & 352 & 177 & 116 & 61 & \\
\hline & $57.6 \%$ & $21.2 \%$ & $10.6 \%$ & $7.0 \%$ & $3.7 \%$ & \\
\hline \multicolumn{7}{|c|}{ Percentage of zip code Black } \\
\hline \multirow[t]{2}{*}{ Black firms } & 242 & 61 & 7 & 1 & 0 & 311 \\
\hline & $77.8 \%$ & $19.6 \%$ & $2.3 \%$ & $0.3 \%$ & $0.0 \%$ & \\
\hline \multirow[t]{2}{*}{ Hispanic firms } & 421 & 42 & 17 & 0 & 0 & 480 \\
\hline & $87.7 \%$ & $8.8 \%$ & $3.5 \%$ & $0.0 \%$ & $0.0 \%$ & \\
\hline \multirow[t]{2}{*}{ Asian firms } & 247 & 111 & 32 & 5 & 0 & 395 \\
\hline & $62.5 \%$ & $28.1 \%$ & $8.1 \%$ & $1.3 \%$ & $0.0 \%$ & \\
\hline \multirow[t]{2}{*}{ White female firms } & 382 & 68 & 5 & 0 & 0 & 455 \\
\hline & $84.0 \%$ & $14.9 \%$ & $1.1 \%$ & $0.0 \%$ & $0.0 \%$ & \\
\hline \multirow[t]{2}{*}{ Number of firms } & 1292 & 282 & 61 & 6 & 0 & 1641 \\
\hline & $78.7 \%$ & $17.2 \%$ & $3.7 \%$ & $0.4 \%$ & $0.0 \%$ & \\
\hline \multirow[t]{2}{*}{ Zip codes } & 1510 & 113 & 37 & 4 & 0 & \\
\hline & $90.7 \%$ & $6.8 \%$ & $2.2 \%$ & $0.2 \%$ & $0.0 \%$ & \\
\hline
\end{tabular}

Caltrans, California Department of Transportation; DBE, disadvantaged business enterprises

market. Firms located far from a construction work site tend to bid higher than firms located close by, and distance is an important element in the market entry decision.
The goal of this section is to estimate the effect of segregation on the number of districts a firm is qualified to serve. A segregated firm is defined as one located in a zip code that is in the fifth quintile of the 

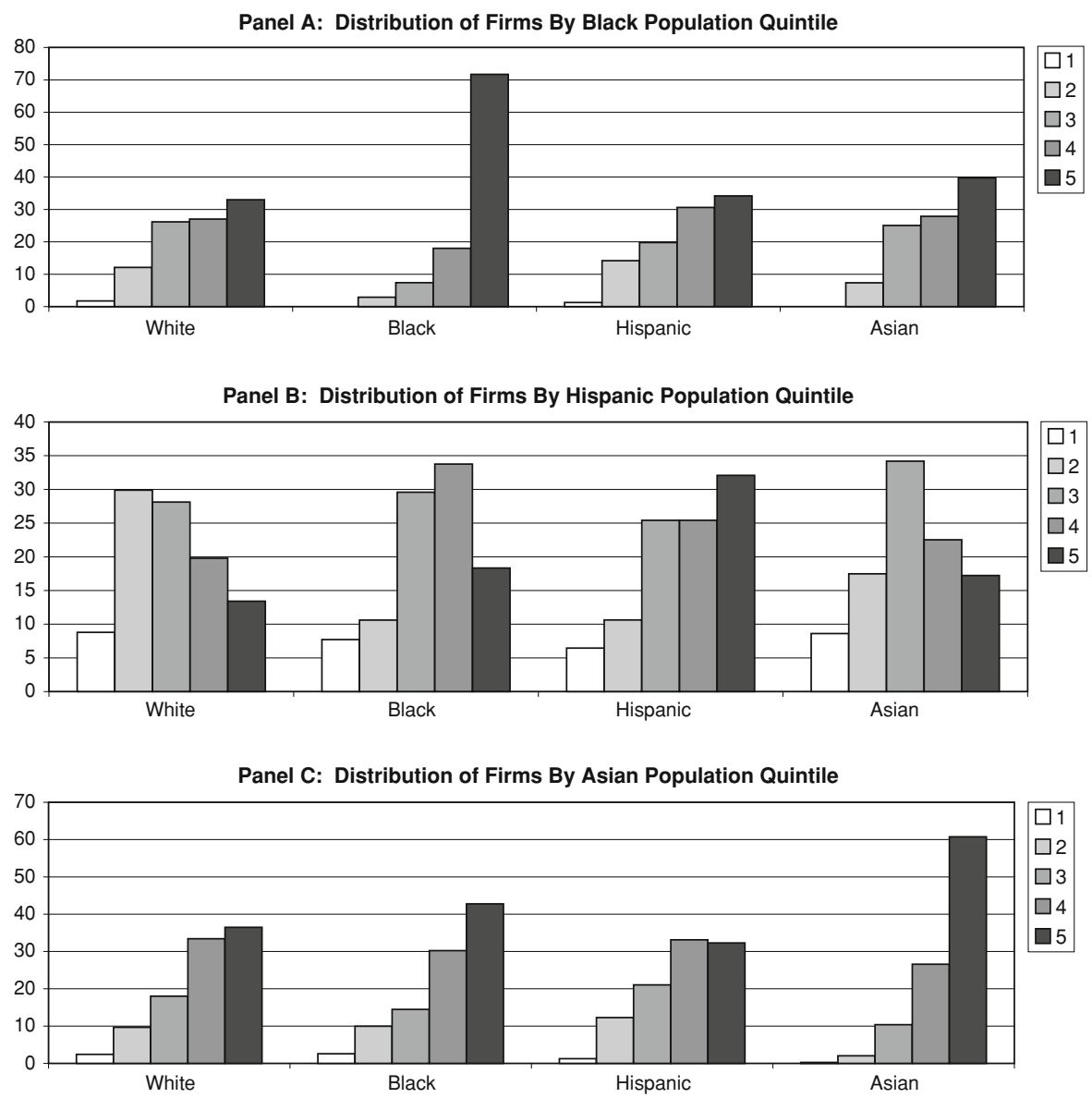

Fig. 1 Distribution of firms by race of owner and zip code race population quintile

own-race population distribution. The regression to be estimated is

districts $_{i t}=\beta_{0}+\beta_{1} s_{i}+\sum_{k}\left[\beta_{2}^{k} r_{i}^{k}+\beta_{3}^{k} q 5_{i}^{k}\right]+\varepsilon_{i}$

where $s_{i}$ is an indicator for a firm being segregated, and $r_{i}$ and $q 5_{i}$ are a series of dummy variables indicating the race of the firm and whether the firm's location is in the fifth quintile of the population distribution of race $k$. Therefore, the variable $s_{i}$ is an interaction between the race indicator and the fifth quintile indicator. I will include in this regression only firms owned by white women and those owned by black, Hispanic, and Asian men and women. ${ }^{7}$

\footnotetext{
7 The directory also has 96 firms owned by American Indians, Portuguese, and Spanish. These firms are excluded due to the small population of American Indians and since segregation is
}

The results are presented in Table 2. In column 1, I consider a specification that only includes the set of race indicators. Compared to firms owned by white women, Hispanic-owned firms serve 0.7 fewer districts, and black-owned firms serve 2.0 fewer districts. Asian firms serve 0.2 fewer districts, though this figure is statistically insignificant and small compared to the average of 8.6 districts.

In column 2, I present a specification that includes the segregation dummy variable, as well as indicators for being located in the fifth quintile of the population distribution of the different racial categories. We see that firms located in zip codes with the highest concentration of black residents serve 1.4 fewer districts, although firms located in fifth quintile

Footnote 7 continued difficult to evaluate and potentially less relevant for Portuguese and Spanish individuals. 
Fig. 2 California Department of Transportation districts

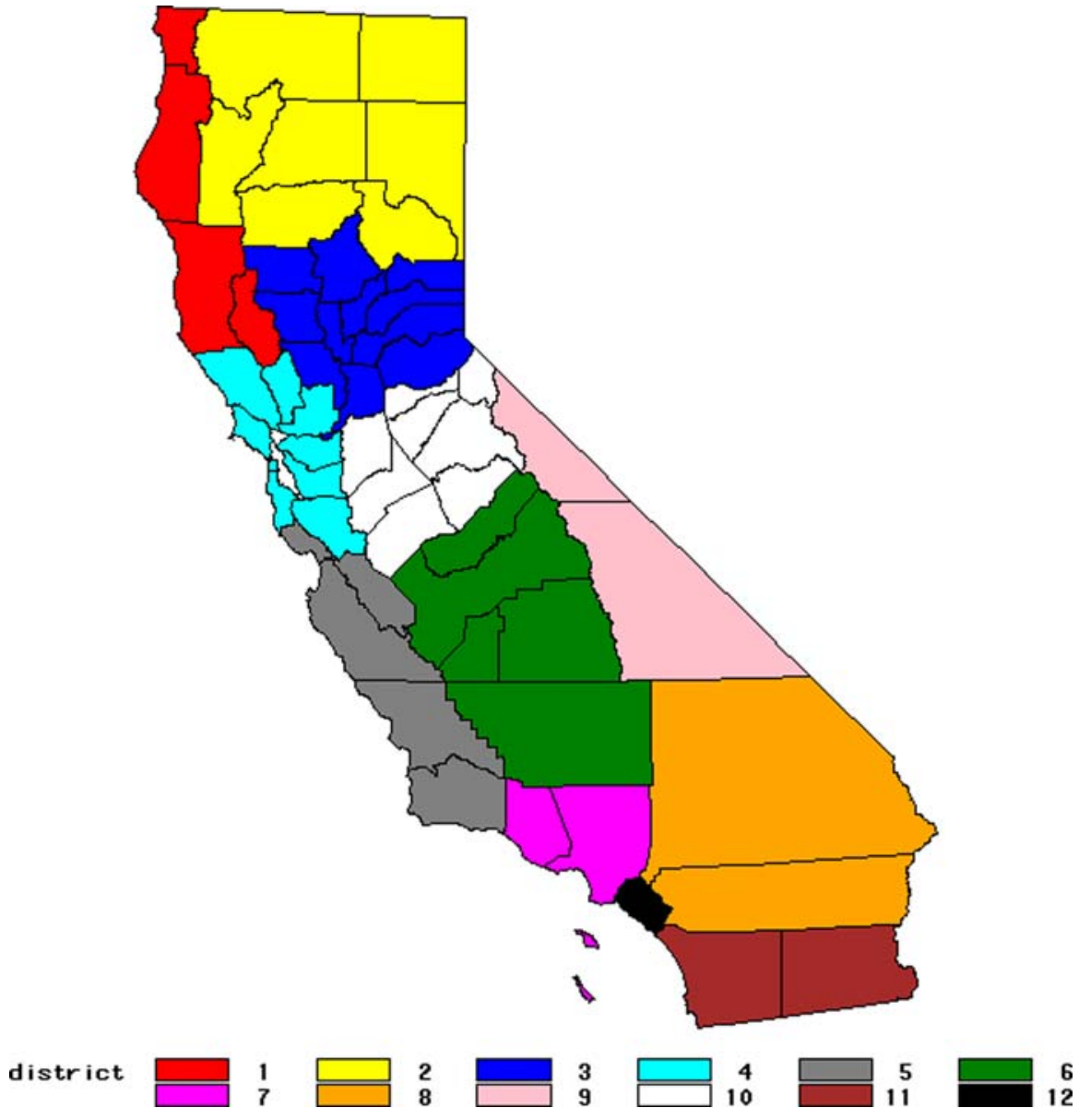

Hispanic and Asian neighborhoods do not serve a statistically significant different number of districts. Segregation seems to be a positive factor in the capabilities of minority-owned firms. Segregated firms serve 1.1 more districts than non-segregated firms.

In Column 3, I split the effect of segregation by race, and we see that the effect of segregation is not evenly spread across races. Black firms experience a significantly positive affect of segregation, and this is enough to overcome the smaller market size they see on average. Consistent with the results shown in Columns 1 and 2, the results shown in Column 3 suggest that black-owned firms are found to serve 2.4 fewer districts than their white-owned counterparts. However, black-owned firms located in zip codes with the highest share of black residents serve an almost identical number of districts as white firms in the same areas and serve 1.1 more districts than other black-owned firms located in areas with lower concentrations of black residents. Conversely, there is no effect of segregation on firms owned by Hispanics or Asians. Furthermore, while the specification in column 2 suggests that Hispanic firms serve smaller markets than white-owned firms, once the effect of segregation is separately estimated by race, I find no difference in geographic market size between Hispanic- and white-owned firms.

It is possible that unobserved factors at the zip code level influence firm size. In evaluating the effects of segregation, much of this is captured by comparing minority firms located in minority areas with white-owned firms located in minority areas. However, the estimated effect of segregation will still be biased if the minority areas that minority-owned firms locate in are different than the minority areas in which white-owned firms locate. To account for this possibility, I include zip code fixed effects in the 
Table 2 Firm segregation and breadth of capability

\begin{tabular}{|c|c|c|c|c|c|}
\hline & \multicolumn{5}{|c|}{ Number of qualified districts in which a firm is qualified to perform work } \\
\hline & Column 1 & Column 2 & Column 3 & Column 4 & Column 5 \\
\hline Asian firm & $\begin{array}{l}-0.225 \\
(0.365)\end{array}$ & $\begin{array}{l}-0.545 \\
(0.400)\end{array}$ & $\begin{array}{l}-0.460 \\
(0.487)\end{array}$ & $\begin{array}{l}-0.246 \\
(0.658)\end{array}$ & $\begin{array}{l}-0.146 \\
(0.733)\end{array}$ \\
\hline Hispanic firm & $\begin{array}{l}-0.696 \\
(0.275)^{* *}\end{array}$ & $\begin{array}{l}-1.540 \\
(0.414)^{* * *}\end{array}$ & $\begin{array}{l}-0.858 \\
(0.548)\end{array}$ & $\begin{array}{l}0.343 \\
(0.890)\end{array}$ & $\begin{array}{l}1.060 \\
(0.914)\end{array}$ \\
\hline Black firm & $\begin{array}{l}-2.016 \\
(0.441)^{* * *}\end{array}$ & $\begin{array}{l}-1.930 \\
(0.448)^{* * *}\end{array}$ & $\begin{array}{l}-2.420 \\
(0.511)^{* * *}\end{array}$ & $\begin{array}{l}-0.803 \\
(0.667)\end{array}$ & $\begin{array}{l}-0.546 \\
(0.736)\end{array}$ \\
\hline Segregated & & $\begin{array}{l}1.063 \\
(0.383)^{* * *}\end{array}$ & & & \\
\hline Black segregated firm & & & $\begin{array}{l}2.222 \\
(0.655)^{* * *}\end{array}$ & $\begin{array}{l}2.114 \\
(0.934)^{* *}\end{array}$ & $\begin{array}{l}1.860 \\
(0.953)^{*}\end{array}$ \\
\hline Hispanic segregated firm & & & $\begin{array}{l}0.189 \\
(0.603)\end{array}$ & $\begin{array}{l}-0.527 \\
(0.981)\end{array}$ & $\begin{array}{l}-0.454 \\
(0.975)\end{array}$ \\
\hline Asian segregated firm & & & $\begin{array}{l}0.895 \\
(0.560)\end{array}$ & $\begin{array}{l}0.333 \\
(0.903)\end{array}$ & $\begin{array}{l}0.218 \\
(1.005)\end{array}$ \\
\hline Black zip code & & $\begin{array}{l}-1.398 \\
(0.341)^{* * *}\end{array}$ & $\begin{array}{l}-1.153 \\
(0.352) * * *\end{array}$ & & \\
\hline Hispanic zip code & & $\begin{array}{l}0.620 \\
(0.389)\end{array}$ & $\begin{array}{l}0.261 \\
(0.399)\end{array}$ & & \\
\hline Asian zip code & & $\begin{array}{l}-0.134 \\
(0.353)\end{array}$ & $\begin{array}{l}-0.207 \\
(0.363)\end{array}$ & & \\
\hline Zip code effects & & & & $\mathrm{X}$ & $\mathrm{X}$ \\
\hline Work code dummies & & & & & $\mathrm{X}$ \\
\hline Observations & 1860 & 1860 & 1860 & 1860 & 1860 \\
\hline$R^{2}$ & 0.03 & 0.06 & 0.07 & 0.56 & 0.65 \\
\hline
\end{tabular}

Standard errors corrected for clustering by zip code are given in parenthesis. The dependent variable is the number of districts in which a firm is qualified to perform work

$* * *, * *, *$ Indicates significance at the $99 \%, 95 \%$, and $90 \%$ levels, respectively

specification shown in column 4 . The results indicate that the estimated effect of segregation for blackowned firms is not due to differences in zip code characteristics. Segregated black firms serve 2.1 more districts than non-segregated black firms. Interestingly, zip code effects are able to account for most of the size differences of white-owned firms and nonsegregated black-owned firms. In the specification presented in column 4, I include controls for the firm's primary category of work. Some types of work may involve lower transportation costs, and these controls will account for any differences in the distribution of races across types of work. In this specification, segregated black firms are still estimated to experience a positive effect of locating in black neighborhoods, although controlling for work codes can account for one-third of the effect.

\subsection{Affirmative action and the number of establishments}

In this section, I consider the effect of affirmative action on the number of highway construction establishments in minority neighborhoods. As we saw in Sect. 4.1, firms tend to be segregated racially. Therefore, understanding how affirmative action affects the number of establishments may tell us how it alters the survival and formation rates of minority-owned firms. This question has proved to be difficult to answer, as data rarely allow one to observe 
both measures of firm success, the race of the owner, and whether a firm is a government contractor. Furthermore, obtaining exogenous changes in affirmative action is difficult.

I will use the Zip Code Business Patterns data to examine how the number of highway construction establishments located in areas with high minority populations in California changed around the time of the implementation of Proposition 209, which eliminated the consideration of race and gender in the awarding of state contracts. As we saw above, Proposition 209 was approved by voters in 1996; however, it was not broadly implemented in public procurement until an executive order by Governor Wilson in early 1998. This Proposition represents plausibly exogenous variation in the degree of affirmative action in procurement.

One objective of examining changes in the number of highway construction establishments in highminority areas is to indirectly measure how affirmative action alters the net survival of minority-owned firms. The highway construction industry is mostly composed of firms selling to the government, as $72 \%$ of revenues in this industry derive from public sources according to the 2002 Census of Construction. By examining firms in this industry, I am almost exclusively studying public contractors and, therefore, those firms most impacted by public procurement policies, such as affirmative action. This combined with the observed segregation of minority firms indicate that changes in the number of highway construction establishments in high minority areas may, under certain circumstances, tell us a considerable amount about the effect of affirmative action on the net survival rates of minority establishments.

Using the Zip Code Business Patterns data, the measure of business outcomes I will use is the number of establishments in the construction industry and, more specifically, in the highway construction industry, before and after affirmative action in California procurement was significantly curtailed in 1998. Firms in these industries are likely to sell to the government, and the average minority-owned firm in these industries will have been more strongly affected by state affirmative action programs than minority-owned firms in other industries. I will use the timing of this policy change to identify the effect of affirmative action on businesses located in minority areas.
Examining highway construction establishments in high-minority areas may-under some circumstances-yield direct evidence of the effect of affirmative action on minority firms. In the extreme case, if predominantly black zip codes are comprised entirely of black-owned firms, then any change in the number of establishments in these zip codes represents a net change in black-owned establishments. In the intermediate case, where firms in predominantly black zip codes are merely more likely to be blackowned, the main assumption that is required is that white entrants are distributed geographically similarly to white incumbents. The elimination of affirmative action reduces the demand from black-owned firms and increases the demand from white-owned firms, which may induce white entry and black exit. If the white-owned firm enters the same zip code that the black firm exits, then even if affirmative action had an adverse effect on minority firm success, it could not be detected by looking at the overall number of establishments in a zip code, even if the firms there are most often black-owned. It is therefore necessary to assume that white entrants are distributed geographically similarly to white incumbents. This is likely a reasonable assumption here, as establishments are being measured at the zip code level, yet the relevant market in the construction industry is geographically much broader. Therefore, even if minority exit leads to entry by a white firm, the characteristics of the road construction industry do not suggest that the firm will be induced to enter the exact zip code where the exit occurred.

The empirical strategy is to compare the number of construction establishments in high-minority zip codes with that observed in other areas of the state. This comparison can be done conditional on overall business activity in the state, which picks up any underlying shocks affecting high-minority areas. This suggests a difference-in-difference (DD) specification of the form

$$
\begin{aligned}
y_{i t}= & \gamma_{0}+\gamma_{1} I(\text { year } \geq 1998) * q 5_{i}^{k}+\gamma_{2} x_{i t}+\varphi_{t}+\rho_{i} \\
& +v_{i t}
\end{aligned}
$$

where $y_{i t}$ measures either the log number of highway construction establishments or the log number of construction establishments. Since only $33 \%$ of zip codes have highway construction establishments, one specification will also consider a linear probability 
model where the dependent variable is an indicator for having a construction establishment. The variable $I($ year $\geq 1998)$ is an indicator for being in the postProposition 209 period, and $q 5_{i}$ is a dummy variable indicating whether the zip code is in the fifth quintile of the distribution of either blacks, Hispanics, or Asians. The coefficient of interest is therefore $\gamma_{1}$, which describes the difference in establishments between high-minority and low-minority areas, before and after the contraction in affirmative action. Unobserved differences across zip codes are captured in the zip code fixed effects, $\rho_{i}$, which also captures the direct effect of being in the fifth quintile of the racial distribution. Common shocks affecting all firms in a given time period are captured by the year effects, $\varphi_{t}$.

Finally, in each specification I will also control for the $\log$ number of non-construction establishments, $x_{i t}$, located in zip code $i$. Zip codes may be hit by year-to-year shocks that affect firm formation and survival, and if these shocks differentially affect minority neighborhoods and are correlated with the implementation of Proposition 209, this will bias the estimates of $\gamma_{1}$. By controlling for the number of nonconstruction establishments, this specification captures unobserved factors affecting business formation at the zip code level. Therefore, for any unobserved variables to bias the estimated coefficients, they would have to differentially affect construction establishments specifically located in high-minority zip codes. Controlling for non-construction establishments could introduce bias if there are firms in the non-construction sector who could also be adversely affected by affirmative action. This bias is likely to be small, since public procurement represents a small portion of the non-construction sector and, furthermore, this effect will bias our estimates of $\gamma_{1}$ toward zero and away from finding an effect.

Table 3 presents estimates of (Eq. 2). The specifications shown in Columns 1-3 separately estimate (Eq. 2) for black, Hispanic, and Asian neighborhoods. Since there may be overlap between the neighborhoods, the specification shown in Column 4 considers them simultaneously. In Panel A, results are presented where the $\log$ of the number of highway construction establishments is the dependent variable. After Proposition 209, zip codes in the fifth quintile of the Black and Asian distribution experienced a decline in the number of highway construction establishments, though the estimate for Black zip codes is insignificant. Hispanic zip codes experienced an increase in highway construction establishments post-Prop. 209. It is worth noting that Hispanic firms were far less segregated in highly Hispanic neighborhoods than firms of other races.

As one-third of zip codes have no highway construction establishments, examining the $\log$ of this variable may miss important variation on the extensive margin. Panel B of Table 3 presents similar DD specifications with an indicator for whether a zip code has a highway construction establishment. ${ }^{8} \mathrm{~A}$ similar pattern emerges. Fifth quintile black and Asian zip codes are, respectively, 2.6 and $2.1 \%$ less likely to have a highway construction establishment post-Proposition 209 relative to other zip codes, and these estimates are statistically significant. Fifth quintile Hispanic zip codes are again slightly more likely to have an establishment after Proposition 209; however, this estimate is statistically insignificant.

The specifications shown in Panel $\mathrm{C}$ of Table 3 consider the change in construction establishments more generally. It is important to consider these establishments for two reasons. First, firms in the construction industry, even those outside of road construction, derive a substantial fraction of their revenue from selling to the government. Blanchflower and Wainwright (2005) indicate that $22 \%$ of revenue in this industry can be attributed to government sources. Second, firms within the construction industry that do not sell to the government represent potential entrants into the public procurement market, perhaps more so than for other industries. For instance, it may be relatively easy for a firm that constructs buildings exclusively in the private sector to begin constructing buildings for the government. The results indicate that black zip codes see a decline in the number of construction establishments of 3.5\% relative to other zip codes. Interestingly, in the broader construction industry, fifth quintile Hispanic zip codes in fact see a decline in the number of construction establishments of $4.4 \%$, which stands in contrast to the experience of these zip codes in the more specific highway construction industry. Fifth

\footnotetext{
${ }^{8}$ Similar results are obtained if a probit is used rather than the linear probability model.
} 
Table 3 Proposition 209 and the number of California establishments

\begin{tabular}{|c|c|c|c|c|}
\hline & Column 1 & Column 2 & Column 3 & Column 4 \\
\hline \multicolumn{5}{|c|}{ Panel A: Log number of highway construction establishments } \\
\hline Post-209_Black zip code & $\begin{array}{l}-0.038 \\
(0.026)\end{array}$ & & & $\begin{array}{l}-0.039 \\
(0.027)\end{array}$ \\
\hline Post-209-Hispanic zip code & & $\begin{array}{l}0.050 \\
(0.028)^{*}\end{array}$ & & $\begin{array}{l}0.061 \\
(0.029) * *\end{array}$ \\
\hline Post-209-Asian zip code & & & $\begin{array}{l}-0.080 \\
(0.026)^{* * *}\end{array}$ & $\begin{array}{l}-0.077 \\
(0.026)^{* * *}\end{array}$ \\
\hline Log(Non-construction establishments) & $\begin{array}{l}0.068 \\
(0.064)\end{array}$ & $\begin{array}{l}0.079 \\
(0.064)\end{array}$ & $\begin{array}{l}0.074 \\
(0.063)\end{array}$ & $\begin{array}{l}0.076 \\
(0.064)\end{array}$ \\
\hline Observations & 4487 & 4487 & 4487 & 4487 \\
\hline$R^{2}$ & 0.71 & 0.71 & 0.72 & 0.72 \\
\hline \multicolumn{5}{|c|}{ Panel B: Highway construction establishments $\geq 0$} \\
\hline Post-209_-Black zip code & $\begin{array}{l}-0.028 \\
(0.013)^{* *}\end{array}$ & & & $\begin{array}{l}-0.026 \\
(0.013)^{* *}\end{array}$ \\
\hline Post-209-Hispanic zip code & & $\begin{array}{l}0.004 \\
(0.012)\end{array}$ & & $\begin{array}{l}0.008 \\
(0.012)\end{array}$ \\
\hline Post-209-Asian zip code & & & $\begin{array}{l}-0.025 \\
(0.012)^{* *}\end{array}$ & $\begin{array}{l}-0.021 \\
(0.012)^{*}\end{array}$ \\
\hline Log(Non-construction establishments) & $\begin{array}{l}0.083 \\
(0.016)^{* * *}\end{array}$ & $\begin{array}{l}0.084 \\
(0.016)^{* * *}\end{array}$ & $\begin{array}{l}0.085 \\
(0.016)^{* * *}\end{array}$ & $\begin{array}{l}0.084 \\
(0.016)^{* * *}\end{array}$ \\
\hline Observations & 13411 & 13411 & 13411 & 13411 \\
\hline$R^{2}$ & 0.70 & 0.70 & 0.70 & 0.70 \\
\hline \multicolumn{5}{|c|}{ Panel C: Log number of construction establishments } \\
\hline Post-209-Black zip code & $\begin{array}{l}-0.041 \\
(0.009)^{* * *}\end{array}$ & & & $\begin{array}{l}-0.035 \\
(0.009)^{* * *}\end{array}$ \\
\hline Post-209-Hispanic zip code & & $\begin{array}{l}-0.049 \\
(0.010)^{* * *}\end{array}$ & & $\begin{array}{l}-0.044 \\
(0.010)^{* * *}\end{array}$ \\
\hline Post-209_Asian zip code & & & $\begin{array}{l}-0.003 \\
(0.008)\end{array}$ & $\begin{array}{l}0.002 \\
(0.008)\end{array}$ \\
\hline Log(Non-construction establishments) & $\begin{array}{l}0.466 \\
(0.034)^{* * *}\end{array}$ & $\begin{array}{l}0.463 \\
(0.034)^{* * *}\end{array}$ & $\begin{array}{l}0.468 \\
(0.033) * * *\end{array}$ & $\begin{array}{l}0.462 \\
(0.034)^{* * *}\end{array}$ \\
\hline Observations & 13411 & 13411 & 13411 & 13411 \\
\hline$R^{2}$ & 0.98 & 0.98 & 0.98 & 0.98 \\
\hline
\end{tabular}

$* * *, * *, *$ Indicates significance at the $99 \%, 95 \%$, and $90 \%$ level respectively

Robust standard errors are given in parenthesis. Other controls include zip code fixed effects and year dummies. A black zip code is defined as one falling in the fifth quintile of the black population distribution. Hispanic and Asian zip codes are similarly defined

quintile Asian zip codes saw little change in the number of establishments in the broader construction industry.

Taken together, the results suggest that black neighborhoods experienced a decline in the number of establishments in industries likely to serve the government, and there is evidence that Hispanic and Asian neighborhoods may have been similarly adversely affected. While Hispanic areas saw an increase in highway construction establishments postProposition 209, the broader construction industry experienced a decline. It is also worth repeating that Hispanic-owned firms appear to be less segregated into Hispanic neighborhoods than firms of other races, which may help explain the mixed results obtained for these zip codes. 


\section{Conclusion}

This paper provides new evidence regarding the segregation of firms across racial lines in the highway construction industry. Minority-owned firms are more likely to locate in zip codes with a high concentration of minority residents. Furthermore, this segregation appears to be a positive factor in the breadth of firm capabilities, at least for black-owned firms. When affirmative action is significantly curtailed in California state procurement, we see evidence of a decline in construction establishments, and in highway construction establishments more specifically, in black neighborhoods. Furthermore, zip codes with high Asian concentrations also see a decline in the number of highway construction establishments. However, the evidence is mixed regarding the effect of Proposition 209 on the number of establishments in Hispanic neighborhoods. This result suggests that eliminating affirmative action may have an adverse impact on either the net survival rates or the size of minority-owned firms.

Acknowledgments I appreciate the helpful comments of Rob Fairlie, Maggie Levenstein, and participants of the Research Conference on Minorities and Women in Entrepreneurship. Funding from the UC Institute for Labor and Employment and UNC Kenan Flagler Institute is gratefully acknowledged.

Open Access This article is distributed under the terms of the Creative Commons Attribution Noncommercial License which permits any noncommercial use, distribution, and reproduction in any medium, provided the original author(s) and source are credited.

\section{References}

Bates, T., \& Williams, D. (1996). Do preferential procurement programs benefit minority business? The American Economic Review, 86(2), 294-297.

Blanchflower, D. G., \& Wainwright, J. (2005). An analysis of the impact of affirmative action programs on selfemployment in the construction industry. National Bureau of Economic Research (NBER) Working Paper no. 6840. Cambridge, MA: NBER

Bollinger, C., \& Ihlanfeldt, K. (2003). The intra-urban distribution of employment: Which government interventions make a difference? Journal of Urban Economics, 53, 396412.

Brueckner, J., \& Zenou, Y. (2003). Space and unemployment: The labor-market effects of spatial mismatch. Journal of Labor Economics, 21, 242-266.
Chatterji, R., Chay, K., \& Fairlie, R. (2009). The impact of contracting set-asides on black self-employment and employment. Working paper. Santa Cruz: University of California Santa Cruz.

Cutler, D., \& Glaeser, E. (1997). Are ghettos good or bad? Quarterly Journal of Economics, 112, 827-872.

Davidsson, P., \& Honig, B. (2003). The role of social and human capital among nascent entrepreneurs. Journal of Business Venturing, 18(3), 301-331.

Fairlie, R. W., \& Marion, J. (2008). Affirmative action programs and business ownership among minorities and women. Working paper. Santa Cruz: University of California Santa Cruz.

Fairlie, R. W., \& Robb, A. M. (2007). Why are black-owned businesses less successful than white-owned businesses: The role of families, inheritances, and business human capital. Journal of Labor Economics, 25(2), 289-323.

Gil, R., \& Hartmann, W. R. (2007). Airing your dirty laundry: Social networks, reputational capital and vertical integration. Working paper. Santa Cruz: University of California Santa Cruz

Holzer, H. (1991). The spatial mismatch hypothesis: What has the evidence shown? Urban Studies, 28, 105-122.

Kain, J. F. (1968). Housing segregation, Negro employment and metropolitan decentralization. The Quarterly Journal of Economics, 82, 175-197.

Kalnins, A., \& Chung, W. (2005). Social capital, geography, and survival: Gujarati immigrant entrepreneurs in the U.S. lodging industry. Management Science, 52(2), 233-247.

Marion, J. (forthcoming a). Affirmative action and the utilization of minority- and women-owned businesses in highway procurement. Economic Inquiry.

Marion, J. (forthcoming b) How costly is affirmative action? Government contracting and California's Proposition 209. Review of Economics and Statistics.

Raphael, S. (1998). The spatial mismatch hypothesis of black youth unemployment: Evidence from the San Francisco Bay area. Journal of Urban Economics, 43, 79-111.

Rauch, J. E. (2001). Black ties only? Ethnic business networks, intermediaries, and African-American retail entrepreneurship. In J. E. Rauch \& A. Casella (Eds.), Networks and markets (pp. 270-309). New York: Russell Sage Foundation.

Shane, S., \& Cable, D. (2002). Network ties, reputation, and the financing of new ventures. Management Science, 48(3), 64-81.

Stoll, M. A. (1999a). Spatial job search, spatial mismatch and the employment and wages of racial and ethnic groups in Los Angeles. Journal of Urban Economics, 46, 129-155.

Stoll, M. A. (1999b). Spatial mismatch, discrimination, and male youth employment in the Washington, DC area: Implications for residential mobility programs. Journal of Policy Analysis and Management, 18, 77-98.

Stoll, M. A., Holzer, H. J., \& Ihlanfeldt, K. R. (2000). Within cities and suburbs: Racial residential concentration and the spatial distribution of employment opportunities across sub-metropolitan areas. Journal of Policy Analysis and Management, 19(2), 207-231. 